\title{
Feasibility Study for Production of Biofuel and Chemicals from Marine Microalgae Nannochloropsis sp. Based on Basic Mass and Energy Analysis
}

\author{
Simon Jegan Porphy and Mohammed M. Farid \\ Department of Chemical and Materials Engineering, The University of Auckland, Private Bag 92019, Auckland 1142, New Zealand \\ Correspondence should be addressed to Simon Jegan Porphy, jsim116@aucklanduni.ac.nz
}

Received 9 August 2011; Accepted 2 October 2011

Academic Editor: C. Muraleedharan

Copyright (C) 2012 S. J. Porphy and M. M. Farid. This is an open access article distributed under the Creative Commons Attribution License, which permits unrestricted use, distribution, and reproduction in any medium, provided the original work is properly cited.

\begin{abstract}
Algae are believed to be a good source of renewable energy because of their rapid growth rate and their ability to be cultivated in waste waters or waste land. The algae Nannochloropsis sp. was chosen for this study, where lipids were extracted and transesterified for biodiesel production. The FFA (free fatty acid) content in the lipid was estimated to be $27 \mathrm{wt} \%$ of the total fatty acids. The remaining biomass after lipid extraction was pyrolyzed at $200^{\circ} \mathrm{C}, 300^{\circ} \mathrm{C}$, and $400^{\circ} \mathrm{C}$ to produce solid, liquid, and gas products. The GC/MS showed that the lipids of Nannochloropsis sp. consist of high concentration of polyunsaturated fatty acids (29 wt\%), eicosapentaenoic acid. The bio-oil produced from pyrolysis of algae biomass (after lipid extraction) at $300^{\circ} \mathrm{C}$ was composed of $50 \mathrm{wt} \%$ acetone, $30 \mathrm{wt} \%$ methyl ethyl ketone and $19 \mathrm{wt} \%$ aromatics such as pyrazine and pyrrole. The heating value of bio-oil is $32 \mathrm{MJ} / \mathrm{kg}$ of oil.
\end{abstract}

\section{Introduction}

Biofuels are becoming increasingly interesting as an alternative to fossil fuels due to increasing population, depletion of fossil fuels, global warming, and fluctuations of the crude oil prices. This has led to a rapid growth and development in the alternative and renewable sources of energy. Biofuels are expected to be one of the major sources of renewable energy which mainly comprises of biodiesel and bioethanol [1]. Years of study indicate that various human activities such as deforestation and burning of fossil fuels have led to the increase in the concentration of carbon dioxide in the atmosphere causing global warming [2]. The burning of fossil-derived transportation fuels significantly contributed to greenhouse effect. The most rapidly growing energy sector is the transportation sector, and recent reports [3] indicate that $27 \%$ of worldwide energy is consumed by the transportation sector alone making it an important target for the reduction of green house gases.

Algae, being the fastest growing plant in the world, have potential of producing 23,000 liters of biofuel per acre which is remarkably better compared to crop-based feedstocks [4]. Algae-based biofuels are also known as "third-generation biofuel" which do not compete for agricultural land, water and food [5]. Although algae-based biofeuls have a better potential than crop-based biofuels, algae do not accumulate significant quantities of storage lipids or triacylglycerols unless they are subjected to stress conditions [6]. Thermal degradation of algae biomass produces hydrocarbon gas and oil. The bio-oil may not only be used as a fuel but also for the production of useful chemicals such as resins, fertilizers, solvents, and alcohols [7].

Recent studies have reported [8] that marine species Nannochloropsis sp. are a potential microalgae for biofuel production owing to the fact that they are capable of producing lipid content as high as $27 \%$ (dry weight) and high biomass productivity. This type of algae tends to accumulate larger proportion of triacylglycerols. Moreover, the commercial cultivation of these species is well understood. The lipid productivity of Nannochloropsis sp. is $82 \mathrm{mg} / \mathrm{L}$ day with a biomass growth rate of $0.27 \mathrm{~g} / \mathrm{L} /$ day [8]. Nannochloropsis sp. is capable of producing high concentration of important 
antioxidants such as zeaxanthin and canthaxanthin, which are high-value nutraceutical products. These species are well known for being rich in omega three fatty acids: eicosapentaenoic acid C20:5 (n-3) and Docosahexaenoic acid C22:6 (n-3), they are primarily used in aquaculture industries as a fish food [9].

Several research projects have been carried out on pyrolysis of biomass over the past two decades, and many feedstocks are being considered such as agricultural waste, waste wood, farm waste, hard wood, and crops. Microalgae are also known to be a good candidate for pyrolysis. Microalgae have many advantages over other crop and wood feedstocks because of their high growth rate and because they can be grown on waste waters or waste land $[10,11]$. However, information to support that based on energy balance conducted on the pyrolysis process of algae biomass is limited in the literature.

During pyrolysis the biomass is degraded to smaller molecules via different stages of degradation. First, dehydration takes place followed by devolatilization and decomposition which is the breakdown of complex organic substances into light and heavy crude bio-oil. It actually mimics the natural geological process where the long-chain compounds are broken down into short-chain ones by the effect of high temperature and pressure. Upon condensation the molecules tend to rearrange themselves and lead to the formation of new compounds $[12,13]$. Studies have reported $[14,15]$ that the formation of char is due to the breaking of the relatively weak bonds such as the alkyl-aryl ether bond and repolymerization of volatiles.

The pyrolysis of biomass generally undergoes primary and secondary reactions. The primary reactions of pyrolysis are important because they generally determine the rate of reaction of the overall process. The primary reaction promotes the formation of hydrocarbon gases and oil.

Longer residence time and higher temperatures result in secondary reactions, these reactions produce higher yield of char and other stable compounds such as hydrogen and methane. The pyrolytic conversion (\%) can be determined by using [16]

$$
\begin{aligned}
& \text { Pryolytic conversion }(\%) \\
& \quad=\left[\frac{\text { cell weight }- \text { residue weight }}{\text { cell weight }}\right] \times 100 .
\end{aligned}
$$

The variation in pryolytic conversion represents the potential of conversion of algae biomass into oil and gas. The decrease in pryolytic conversion corresponds to the increase in yield of char, which is a result of the secondary reactions and repolymerization of volatiles.

The thermal gravimetric analysis (TGA) is an analytical technique which is used to measure the weight loss or weight gain with respect to temperature. The whole process can be carried out under inert atmosphere or air. The TGA of algae biomass gives overall information on weight loss with respect to temperature and it can be used to study the overall reaction kinetic. The thermal decomposition studies $[13,16,17]$ of Chlorella protothecoides showed that there were three stages of degradation of biomass, dehydration, devolatilization, and decomposition stage. Dehydration stage was observed from $80^{\circ} \mathrm{C}$ to $150^{\circ} \mathrm{C}$, devolatilization was observed from temperatures $180^{\circ} \mathrm{C}$ to $480^{\circ} \mathrm{C}$ and at this stage around $70 \%$ of the biomass is degraded to release volatiles. The decarboxylation, deoxygenation, and depolymerization occur during the devolatilization stage. Decomposition stage occurs at $500^{\circ} \mathrm{C}$ to $800^{\circ} \mathrm{C}$, which results in the formation of solid residues.

A kinetic study of thermal decomposition of Chlorella protothecoides at different heating rates from $15^{\circ} \mathrm{C} /$ minute to $80^{\circ} \mathrm{C} /$ minute showed that with increasing heating rate the activation energy and the order of the reaction were reduced. Thermal decomposition studies were also done with the lipids completely extracted and partially extracted from the algae biomass. According to Peng higher energy input and temperatures were required for the pyrolysis reaction to occur for the algae biomass composed mainly of crude lipids, that is, $54 \%$ lipids and $10 \%$ proteins. Also, less energy input was needed when the lipids were extracted from the algae biomass giving higher yield of volatiles during the devolatilization stage [13].

The enthalpy change of pyrolysis reaction is the energy required to heat the biomass to the reaction temperature and breakdown the complex organic substances into products such as solid, gas, and liquid. The biomass is a complex organic substance and hence it is difficult to determine the specific heat capacity or energy data needed for energy calculation. Earlier studies [18] have reported that the enthalpy of pyrolysis of pine wood and hard wood biomass is $2.9 \mathrm{MJ} / \mathrm{kg}$ to $3.5 \mathrm{MJ} / \mathrm{kg}$ and $2.5 \mathrm{MJ} / \mathrm{kg}$, respectively. The enthalpy of pyrolysis largely depends on the chemical composition of biomass, reactor temperature, moisture content of the biomass, and pyrolysis reaction chemistry. The wood biomass is composed of lignin, hemicelluloses, and celluloses which are highly complex organic matters and hence requires more energy compared to pyrolysis of algae biomass which is composed of lipids, proteins, and carbohydrates [16, 19-21].

The fatty acid composition determines the following important properties of the fuel produced.

(i) Better cold flow property.

(ii) Oxidative stability.

(iii) Acceptance based on existing standards, that is, the ASTM (American Society for Testing and Materials) and European Standards.

The fatty acid composition mainly contributes to the cold flow property and the oxidative stability. The unsaturated fatty acids have low melting point but high susceptibility to oxidation while saturated fatty acids have high melting point but low susceptibility to oxidation [22]. Therefore, it is important to have an optimum mixture of both unsaturated and saturated fatty acids to satisfy ASTM and European Standards. The degree of unsaturated fatty acids is determined by the iodine value; the European Standard EN 14214 and 14213 requires the biodiesel not to exceed more than $120 \mathrm{~g}$ and $130 \mathrm{~g}$ iodine/100 $\mathrm{g}$ of the biodiesel. Moreover, the European Standards does not accept biodiesel with more than $1 \%$ of four or more double bonds. 
Differential scanning calorimetry (DSC) is a simple analytical technique that can be used for determining the latent heat, glass transition, and crystallization behavior of the fuel which are important for any fuel producers. The cold flow property of the fuel is influenced by the chemical composition so it is important that the fuel is analyzed by gas chromatography in addition to the DSC analysis. It is important to understand the solid-liquid equilibrium data obtained through the DSC analysis for understanding the fluid properties, and this data is limited [23].

The bio-oil produced via pyrolysis of wood biomass is generally composed of aromatics, saturated carbons, alcohols, amines, and acids. Studies have suggested [24] that the aromatics group of compounds show glass transition behavior.

The aims of this study are to (I) extract the lipids of Nannochloropsis sp. for biodiesel production through transesterification and analyze the FAME (Fatty Acid Methyl Ester), (II) conduct pyrolysis of the remaining algae biomass for fuel production and test its quality, (III) assess the energy efficiency of such approach, and (IV) look into the possibility of producing fuel and chemicals from algae biomass through transesterification of the lipid portion and pyrolysis of the remaining spent biomass, while the produced residue could be used for sequestration. However, no proximate analysis has been done in this work to the residue produced, which should be done in future work for its nitrogen, phosphorus, and potassium content if it is going to be used for biochar production.

\section{Materials and Method}

2.1. Sample Preparation. The photographically grown Nannochloropsis sp. CCMP525 (Culture Collection of Marine Phytoplankton) was purchased from Reed Mariculture, Calif, USA ( $1 \mathrm{~kg}$ wet biomass). The concentrated algae biomass was directly dried in a vacuum oven at 800 millibar and $60^{\circ} \mathrm{C}$ for 36 hours until $80 \%$ of the moisture was lost. Then the samples were prepared by pulverisation with mortar and pestle. The lipids from the biomass were extracted by $n$ hexane using a soxhlet apparatus.

2.2. Estimation of FFA. The acid value of the lipids was measured by the AOCS (American Oil Chemist Society) Cd $3 \mathrm{~d}-63$ method and was used to determine the FFA content in the lipid:

$$
\% \text { free fatty acids (oleic acid })=\frac{T \times M \times 28.2}{W},
$$

where, $T$ is the titration value ( $\mathrm{mL}$ of sodium hydroxide), $M$ is the molarity of sodium hydroxide, and $W$ is the weight of sample.

If $28.2 \mathrm{~g}$ sample and $0.1 \mathrm{M} \mathrm{NaOH}$ are used, then:

$$
\% \mathrm{FFA}=\frac{T}{10} .
$$

\subsection{Acid Transesterification}

Saponifying Agent. $1 \mathrm{~g}$ of $\mathrm{NaOH}$ was dissolved in $50 \mathrm{~mL}$ of methanol.

Methylating Agent. $2 \mathrm{~g}$ of $\mathrm{NH}_{4} \mathrm{Cl}_{2}$ was dissolved in $60 \mathrm{~mL}$ methanol with $\mathrm{H}_{2} \mathrm{SO}_{4}$ as a catalyst ( $18 \mathrm{M}, 100 \%$ catalyst) and heated at $60^{\circ} \mathrm{C}$ for about 30 minutes. All the chemicals were purchased from Sigma-Aldrich.

$150 \mathrm{mg}$ of lipid was saponified with $0.5 \mathrm{~mL}$ of saponifying agent and heated to $60^{\circ} \mathrm{C}$ for 1 hour in a water bath. Then $3 \mathrm{~mL}$ of the methylating agent was added and heated to $60^{\circ} \mathrm{C}$ for 1 hour in a water bath. The mixture was cooled down in a cold water bath resulting in the formation of two distinctive layers. The bottom layer is glycerol and other impurities and the top layer is FAME $[25,26] .3 \mathrm{~mL}$ of hexane was used to dissolve the FAME. The FAME was transferred directly into GC vials for GC/MS (gas chromatography/mass spectrum) analysis.

2.4. Gas Chromatographic/Mass Spectrum Analysis. The column used for the fatty acid analysis was Zebron 1701 ( $14 \%$ cyanopropylphenyl and $86 \%$ dimethylpolysiloxane). The column dimensions were $30 \mathrm{~m}$ length $\times 0.25 \mathrm{~mm}$ I.D $\times 0.25 \mu \mathrm{m}$ film thickness, and the temperature profile was: column oven $100^{\circ} \mathrm{C}$, injection $325^{\circ} \mathrm{C}$, detector $395^{\circ} \mathrm{C}$. The heating rate was set as follows: $100^{\circ} \mathrm{C}$ to $145^{\circ} \mathrm{C}$ at $5^{\circ} \mathrm{C} /$ minute, $145^{\circ} \mathrm{C}$ to $148^{\circ} \mathrm{C}$ at $0.5^{\circ} \mathrm{C} /$ minute, and $148^{\circ} \mathrm{C}$ to $200^{\circ} \mathrm{C}$ at $10^{\circ} \mathrm{C} /$ minute. The $\mathrm{GC} / \mathrm{MS}$ analysis was done at School of Biological Sciences, the University of Auckland, Auckland City Campus, New Zealand.

2.5. Thermal Gravimetric Analysis (TGA). The TGA analysis was performed in SHIMADZU TGA-50. The Nannochloropsis sp. dried biomass was subjected to TGA. A sample of $21.1 \mathrm{mg}$ (dry) algae biomass was used. The temperature program was set as follows: heating rate of $10^{\circ} \mathrm{C} /$ minute from ambient temperature to $100^{\circ} \mathrm{C}$ and then $30^{\circ} \mathrm{C} /$ minute up to $800^{\circ} \mathrm{C}$. Constant flow of nitrogen $(99.9 \mathrm{wt} \%$ purity) was maintained at $40 \mathrm{~mL} /$ minute to remove air and avoid any oxidation reaction.

2.6. Pyrolysis of the Algae Biomass. The pyrolysis of the algae biomass after extraction was carried out in a conventional slow pyrolysis semibatch reactor at atmospheric pressure with heating controlled by PID (proportional integral differential) controller.

The pyrolysis setup is shown in Figure $1.50 \mathrm{~g}$ of the dry biomass is loaded into the reactor and the top is sealed. Nitrogen ( $99 \mathrm{wt} \%$ purity) is purged at $30 \mathrm{~mL} / \mathrm{min}$ to remove air from the reactor. The algae biomass was pyrolyzed in the absence of air to prevent oxidation reactions. The pyrolysis was carried out at three different temperatures of $200^{\circ} \mathrm{C}$, $300^{\circ} \mathrm{C}$, and $400^{\circ} \mathrm{C}$ with a heating rate of $30^{\circ} \mathrm{C} /$ minute and residence time of 30 minutes. A cooling water condenser was used to condense the gases; the temperature of the condenser was maintained at $15^{\circ} \mathrm{C}$ using tap water. The pyrolysis of algae biomass (with lipids and without lipids) 


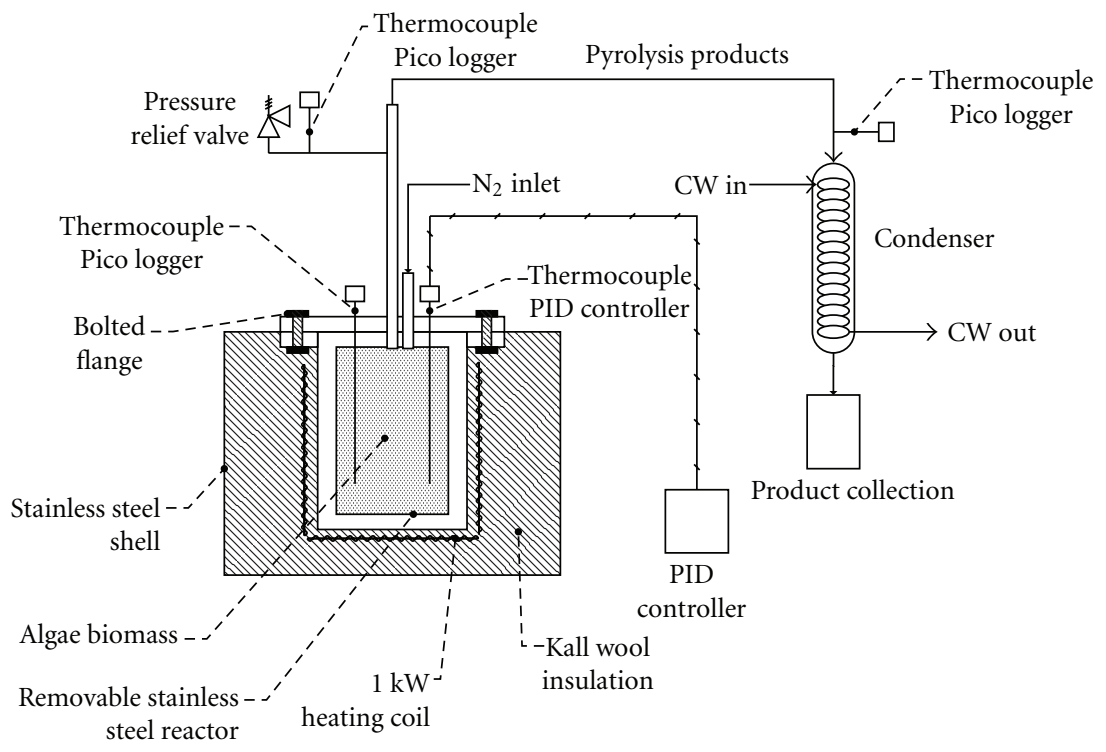

FIGURE 1: Schematic representation of pyrolysis batch reactor.

was carried out for comparison. The yields of char and biooil were calculated by weighting them, and the yield of gas was calculated from the difference. The conversion (\%) of biomass to hydrocarbon gases and oil was determined based on (1).

2.7. Thermal Analysis of the Bio-Oil Using DSC. Thermal analysis of the bio-oil was carried out using the differential scanning calorimetry (DSC SHIMADZU-60) to determine the freezing and melting point. A bio-oil sample of $7 \mathrm{mg}$ was loaded in a sample holder (high pressure aluminium cell, $6 \mathrm{~mm}$ diameter). The temperature program was set to $5^{\circ} \mathrm{C} /$ minute from room temperature to $-40^{\circ} \mathrm{C}$ and then back to room temperature with a heating rate of $5^{\circ} \mathrm{C} /$ minute. The analysis was conducted under the atmosphere of dry air with a constant flow rate of $100 \mathrm{~mL} /$ minute.

2.8. Gas Chromatographic/Mass Spectrum Analysis of the BioOil. An Hp/Agilent GC/MS was used for the qualitative and quantitative analysis of the bio-oil obtained from pyrolysis, and GC column $(30 \mathrm{~m} \times 0.25 \mathrm{~mm}$ DB-VRX, J\&W, 6\% cyanopropylphenyl 94\% dimethylpolysiloxane) was used for the quantitative analysis. The internal standards used were 4-bromofluorobenzene and toluene-d8, Mass spectrum library search was done to identify the compounds in the bio-oil. The tar compounds in the bio-oil were removed using microfilters $(0.1 \mu \mathrm{m}$ pore size $)$. The GC/MS analysis was done at Hills Laboratories, Hamilton, New Zealand.

2.9. Estimation of Heating Value of the Bio-Oil by GC Analysis (Sample Calculations). Using the quantitative and qualitative analysis of the bio-oil from the GC, the heating value of the bio-oil was calculated using:
Heating value of Acetone

$$
\begin{aligned}
& =\frac{\text { enthalpy of combustion }(\mathrm{KJ} / \mathrm{mol}) \times \text { mass fraction }}{\text { molecular weight }(\mathrm{g} / \mathrm{mol})} \\
& =\frac{-1772 \times 0.54}{58.08}=-16.5 \mathrm{MJ} / \mathrm{kg} .
\end{aligned}
$$

\section{Results and Discussion}

The lipids were extracted from the algae biomass by soxhlet apparatus. The algae biomass was found to have $16 \mathrm{wt} \%$ of lipids (dry weight of biomass). Acid value was determined to be $7.64 \mathrm{mg} \mathrm{KOH} / \mathrm{g}$ of the sample, and from the acid value the percentage of FFA was determined as $27 \mathrm{wt} \%$ of the total lipids, which may be considered very high. Lipid with FFA content more than $5 \mathrm{wt} \%$ is not suitable for base catalyzed transesterification as the FFA will tend to consume the catalyst and form soap which will cause serious separation problem to the product. The acid catalyzed transesterification is a slow reaction ( 4 to 8 hours). Hence, a rapid method of acid-catalyzed transesterification was used to convert all the fatty acids into biodiesel. A GC/MS analysis was carried out to the FAME and the compounds shown in Table 1 were identified and quantified.

Figure 2 shows the GC/MS chromatograph of the FAME. Methyl palmitate $(10 \mathrm{wt} \%)$ and methyl palmitoleate (16 wt \%) are the major saturated fatty acid esters. Methyl eicosapentaenoate is the major polyunsaturated fatty acid ester (omega-three fatty acid) which was found to be in high concentrations (29wt\%). According to the European Biodiesel Standards EN 14214 the FAME composition should be limited to $1 \mathrm{~mol} \%$ of four or more double bond. The presence of high concentration of methyl eicosapentaenoate (29wt\%) will affect the cold flow property of the fuel and makes it susceptible to oxidation on storage. The unsaturated 


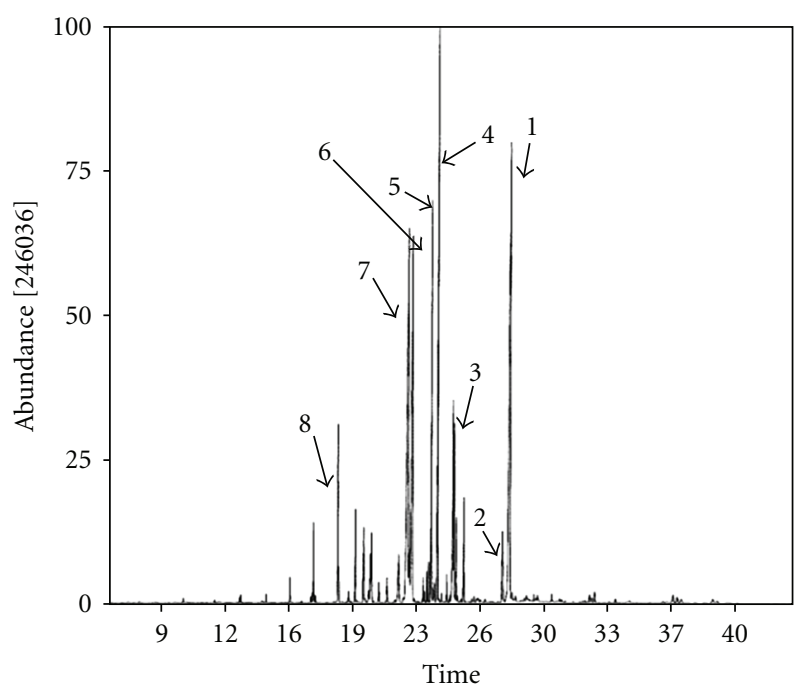

(1) $\operatorname{EPA}(\mathrm{C} 20: 5 \mathrm{n} 3)-29$

(2) Arachidonate $(\mathrm{C} 20: 4 \mathrm{n} 6)$

(3) Linoleate $(\mathrm{C} 18: 2 \mathrm{n} 6)-5.76 \%$

(4) Heptadecanoic acid (C17)

(5) 2-Hexylcclpropaneoetanic acid - derivative of palmitic acid

(6) Methyl palmitate (C16:0) $-10 \%$

(7) Methyl palmitoleate $(\mathrm{C} 16: \ln 7)-16 \%$

(8) Myristic acid (14:0)

$x$ axis: time $(\mathrm{min}) \quad y$ axis: average area

Figure 2: GC/MS analysis of FAME obtained from Nannochloropsis sp.

TABLE 1: FAME composition by GC/MS analysis. The total fatty acid composition did not account for $100 \%$ because some of the peaks were not assigned. Only the fatty acids that affect the quality of the biodiesel were measured.

\begin{tabular}{lc}
\hline Fatty acid & Concentration (w/w\%) \\
\hline Methyl eicosapentaenoic C20:5 (n-3) & $29 \%$ \\
Methyl linoleate C18:2 (n-6) & $5.76 \%$ \\
Methyl palmitate C16:0 & $10 \%$ \\
Methyl palmioleate C16:1 (n-7) & $16 \%$ \\
\hline
\end{tabular}

fatty acids may be converted into saturated fatty acids by relatively simple hydrogenation reaction.

\subsection{Thermal Gravimetric Analysis (TGA) of Nannochloropsis} Biomass. The TGA test conducted on Nannochloropsis sp. CCMP525 provides similar results to that of Chlorella protothecoides as given by Peng et al. [16]. TGA for the Nannochloropsis sp. biomass (after lipid extraction) revealed that there are three stages of thermal degradation. As shown in Figure 3, the first stage is the dehydration stage at temperatures up to $190^{\circ} \mathrm{C}$ where the water bound within the inner cell wall of the algae biomass gets evaporated. The second stage is the devolatilization stage from $190^{\circ} \mathrm{C}$ to $400^{\circ} \mathrm{C}$ where maximum volatiles are released, with the DTG peak being maximum at temperatures ranging from $250^{\circ} \mathrm{C}$ to $350^{\circ} \mathrm{C}$. The last stage is the decomposition stage which occurs at temperatures higher than $600^{\circ} \mathrm{C}$, which results in the formation of solid residue.

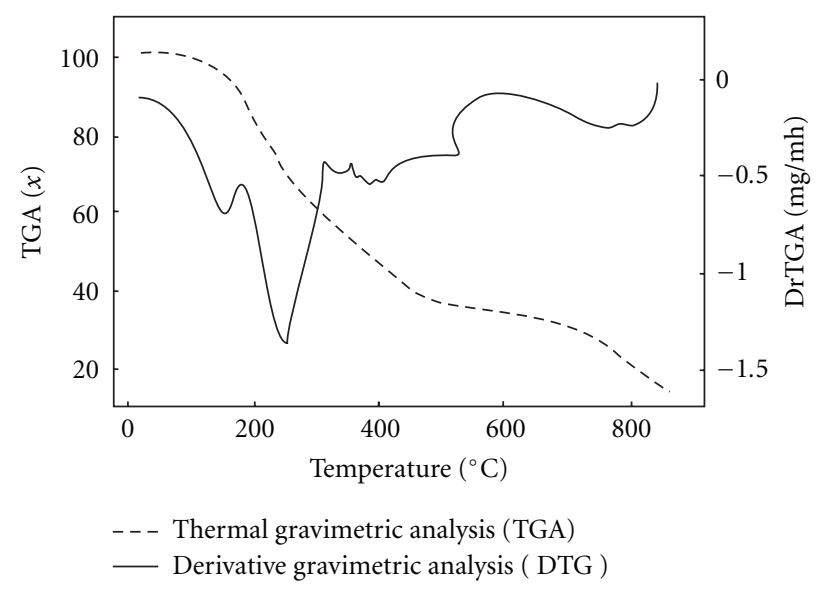

FIgURE 3: Graph of TGA of algae biomass (after lipid extraction).

3.2. Yields of Oil, Gas, and Char from Pyrolysis of Algae Biomass. A maximum yield of bio-oil was observed at a temperature of $300^{\circ} \mathrm{C}$. The yield of bio-oil from the algae biomass (before extraction of lipids) was 30\% (dry mass) while it was only $20 \%$ for the biomass (after extraction of lipids) as shown in Figure 4(b). It is evident from earlier studies $[17,27]$ that the yield of bio-oil reduced with lower triacylglycerols or storage lipids. The yield of bio-oil was poor at $200^{\circ} \mathrm{C}$ and $400^{\circ} \mathrm{C}$. At $200^{\circ} \mathrm{C}$ the yield of residue was as high as $68 \mathrm{wt} \%$ indicating incomplete pyrolysis, and at $400^{\circ} \mathrm{C}$ the yield of residue was only $30 \mathrm{wt} \%$ but the yield of gas was as high as $60 \mathrm{wt} \%$ as shown on Figures 4(a) and 4(b).

The pryolytic conversion (\%) of algae biomass (with lipids) increases $(36.00 \%, 50.04 \%$, and $68.78 \%)$ with increasing temperatures $200^{\circ} \mathrm{C}, 300^{\circ} \mathrm{C}$, and $400^{\circ} \mathrm{C}$, respectively. The pryolytic conversion (\%) of algae biomass (after lipids extraction) behaved the same way $(38.50 \%, 52.00 \%$, and $67.00 \%)$.

3.3. GC/MS of Bio-Oil Obtained via Pyrolysis. The GC/MS of the bio-oil obtained from algae biomass (after lipid extraction) at $300^{\circ} \mathrm{C}$ showed that $50 \mathrm{wt} \%$ of the bio-oil is acetone. Another $30 \mathrm{wt} \%$ is methyl ethyl ketone (MEK), and the remaining $19 \mathrm{wt} \%$ is aromatics such as pyrrole, pyridine compounds and amines were found in traces such as trimethylamine. A list of the compounds identified in the bio-oil is shown in Table 2. The bio-oil also had tar compounds. Previous studies have reported [17] that these tar compounds are asphaltenes which is brownish in color. As the temperature of pyrolysis increases the tar content in the bio-oil also increases.

Studies have reported [7] that bio-oil obtained from pyrolysis of algae biomass (with lipids) contains small fractions of saturated hydrocarbons, industrial chemicals such as fertilizers, resins, sugar-based compounds, alcohol such as furfural alcohol, and pesticides. In contrast to the literature, this work shows that the bio-oil obtained from algae biomass (after lipid extraction) contains mainly solvents acetone and 2-butanone. Figure 5 shows different products obtained from pyrolysis of algae biomass (with 


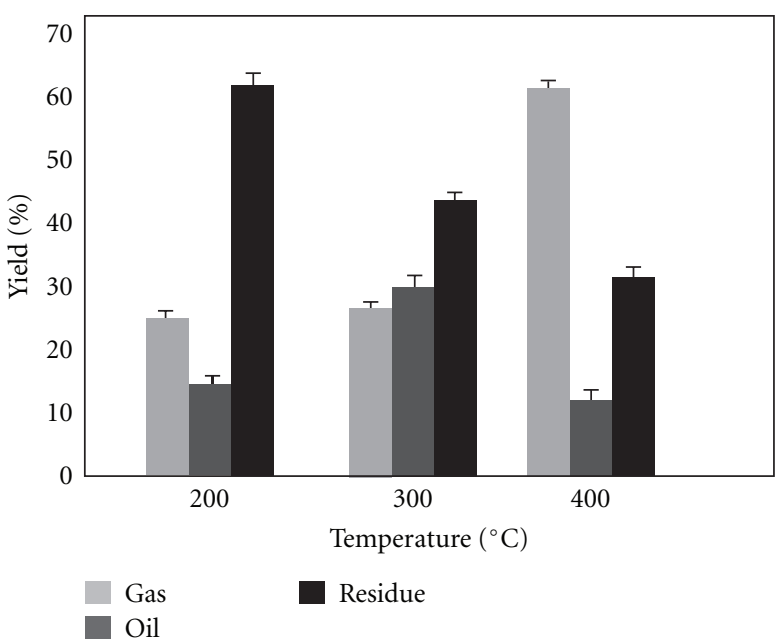

(a)

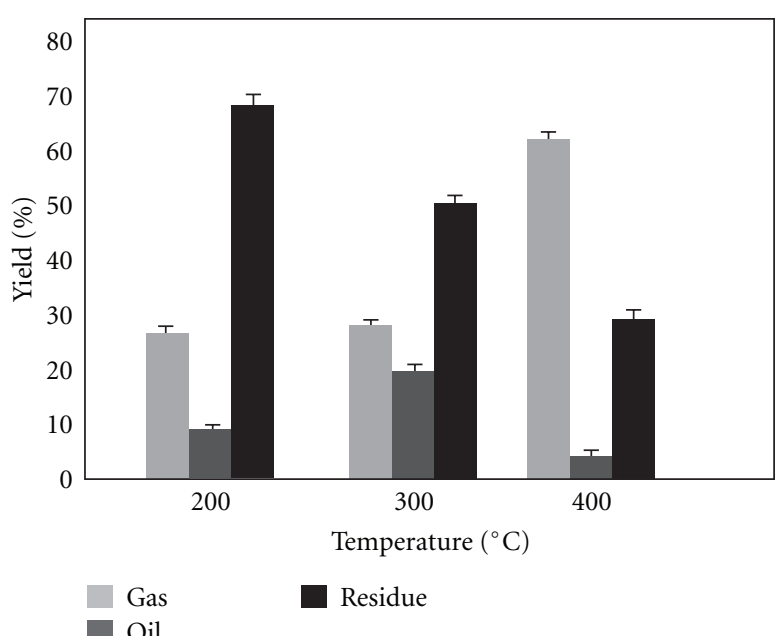

(b)

Figure 4: Yield of pyrolysis products of algae biomass. (a) Pyrolysis of algae biomass (with lipids). (b) pyrolysis of algae biomass (after lipid extraction). $N=3$, mass of sample $=50$ grams.

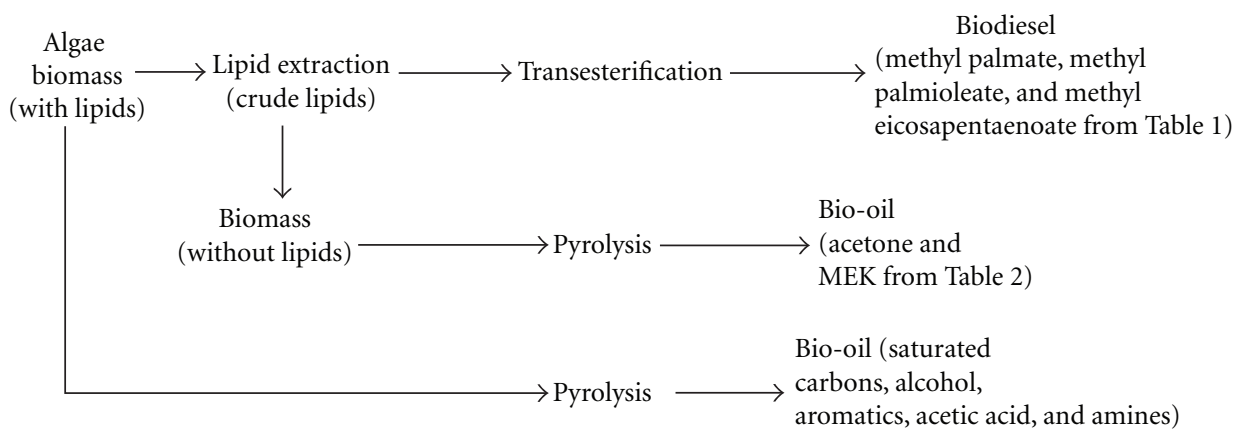

FIGURE 5: Schematic representation of products from different fuel conversion technology.

lipids and without lipids). The solvent 2-butanone is also known as methyl ethyl ketone (MEK). It is used as a solvent in processing of gums, resins, and cellulose acetate, also used in manufacturing of plastics and textiles and can also be used as a cleansing agent. Acetone is commonly used in laboratory as rinsing and drying agent; it is also used as denaturing, degumming and degreasing agent. Thus, algae bio-oil could have large industrial applications in addition to its potential use as a fuel. The heating value of the bio-oil produced in this work was $32 \mathrm{MJ} / \mathrm{kg}$ as shown in Table 2.

3.4. Analysis of the Bio-Oil Using DSC. The freezing and the melting profiles of bio-oil obtained from pyrolysis of biomass (with lipids) and biomass (after lipid extraction) are very different. The biomass (without lipids) produced biooil with lower melting and freezing point. Table 3 shows the thermal properties of the bio-oil products.

The pyrolysis of algae biomass (with and without lipids) at $200^{\circ} \mathrm{C}$ produced bio-oil of low freezing point indicating that the bio-oil is composed of low-molecular-weight compounds. As shown in Figures 6(a), 6(b), and 6(c), the freezing point and the melting point increases when pyrolysis temperature increases, leading to the formation of higher molecular compounds with higher latent heat of melting. Figures 6 and 7 show that there appears to be no glass transitions and crystallization behavior for any of the biooil products. Studies have reported [24] that the presence of aromatics exhibits a crystallization behavior but the bio-oil products obtained from pyrolysis of algae biomass (with and without lipids) did not exhibit such behavior.

3.5. Energy Data. The following assumptions were taken into account in the energy balance made.

(i) The microalgae are cultivated in waste water ponds. These ponds are a good source of nitrogen and heavy metal which are vital for the growth of algae. The algae use sunlight and $\mathrm{CO}_{2}$ via photosynthesis for their growth and development. Hence, the energy required for cultivation was not taken into account.

(ii) Bioflocculation is a natural method of harvesting algal cells to $2 \%$ solids and the cells are further dewatered and concentrated by mechanical action to form an algae cake to $20 \%$ solids. The energy required for harvesting was not considered. 
TABLE 2: GC/MS analysis of bio-oil obtained from pyrolysis of algae biomass (after lipid extraction).

\begin{tabular}{|c|c|c|c|c|c|}
\hline Name of the compound & $\begin{array}{c}\text { Estimated } \\
\text { concentration }\left(\mathrm{g} / \mathrm{m}^{3}\right)\end{array}$ & $\begin{array}{c}\text { Enthalpy of } \\
\text { combustion }(\mathrm{KJ} / \mathrm{mol})\end{array}$ & Mass fraction & $\begin{array}{c}\text { Molecular } \\
\text { mass (g/mol) }\end{array}$ & $\begin{array}{c}\text { Heating value } \\
(\mathrm{MJ} / \mathrm{kg}) \\
\text { at } 25^{\circ} \mathrm{C} \text { and } 1 \mathrm{~atm} \\
\end{array}$ \\
\hline Acetone & 110 & -1772 & 0.5400 & 58.08 & -16.5000 \\
\hline 2-Butonone & 65 & -2444.2 & 0.3200 & 72.11 & -10.8000 \\
\hline Trimethylamine & 7.2 & 0.0360 & 0.0325 & 59 & -1.4900 \\
\hline Propanal,2-methyl & 0.8 & -2469.4 & 0.0040 & 72 & 0.1400 \\
\hline Propanenitrile & 2.3 & -1948.3 & 0.0112 & 55.08 & 0.4000 \\
\hline Butanal,2-methyl & 0.4 & -2560.8 & 0.0020 & 86.13 & 0.0590 \\
\hline Butanenitrile,3-methyl & 3.6 & -3246 & 0.0176 & 86.13 & -0.6887 \\
\hline Pyrrole & 3.1 & -2351.7 & 0.0150 & 67 & -0.5400 \\
\hline Pentanenitrile,4-methyl & 4 & -3637 & 0.0195 & 97 & 0.7348 \\
\hline Pyridine,2-methyl & 0.2 & -3292 & 0.0009 & 93 & -0.0346 \\
\hline 1,3-Butadiene,2-methyl & 0.2 & -3158.2 & 0.0009 & 68 & -0.0455 \\
\hline Total & & & & & $32 \mathrm{MJ} / \mathrm{kg}$ of oil \\
\hline
\end{tabular}

TABLE 3: Thermal properties of bio-oil products.

\begin{tabular}{lcccc}
\hline Bio-oil product & Freezing point ${ }^{\circ} \mathrm{C}$ & Melting point ${ }^{\circ} \mathrm{C}$ & Latent heat freezing $(\mathrm{J} / \mathrm{g})$ & Latent heat melting $(\mathrm{J} / \mathrm{g})$ \\
\hline $200^{\circ} \mathrm{C}$ bio-oil (with lipid) & -41.0 & -8.00 & 120 & -119 \\
$300^{\circ} \mathrm{C}$ bio-oil (with lipid) & -29.0 & 3.00 & 173 & -214 \\
$400^{\circ} \mathrm{C}$ bio-oil (with lipid) & -25.0 & 1.86 & 225 & -204 \\
$300^{\circ} \mathrm{C}$ bio-oil (biomass without lipids) & -37.4 & -2.40 & 174.2 & -140 \\
\hline
\end{tabular}

(iii) It is assumed that the reactor is insulated and the heat is transferred to the biomass efficiently; heat losses were not taken into account.

3.6. Energy for Drying. After the lipids are extracted for biodiesel production the spent biomass can be used for pyrolysis to produce solid, liquid, and gaseous products. It is important to dry the biomass ( $10 \%$ moisture content) for the pyrolysis of biomass under atmospheric conditions. Drying is an energy intensive process due to high latent heat of vaporization of water. Thus, more energy is required to dry the biomass. The energy required for drying the algae biomass to $10 \%$ moisture content using a rotary drum dryer can be determined as follows.

Basis: $1 \mathrm{~kg}$ of Solid Algae. $1 \mathrm{~kg}$ of algae biomass contains $20 \%$ solids and $80 \%$ water content. Equation (5) shows the amount of water to be removed to obtain a $\mathrm{kg}$ of dry algae biomass:

$$
\begin{aligned}
& 1 \text { ( } \mathrm{kg} \text { algae })\left(\frac{0.8 \mathrm{~kg} \text { water }}{0.2 \mathrm{~kg} \text { algae }} \text { in }\right)-\left(\frac{0.1 \mathrm{~kg} \text { water }}{0.9 \mathrm{~kg} \text { algae }} \text { out }\right) \\
& =3.89(\mathrm{~kg} \text { water }) .
\end{aligned}
$$

Hence, as on water latent heat of vaporization equals 2257 $\mathrm{KJ} / \mathrm{kg}$, the amount of energy required to evaporate $3.89 \mathrm{~kg}$ of water is $8.78 \mathrm{MJ} / \mathrm{kg}$ dry algae biomass.

3.7. Energy Requirement for Pyrolysis. The energy needed for the pyrolysis of the biomass to produce solid, liquid, and gases products is calculated using the DSC measurements. Dry biomass powder ( $10 \%$ moisture) was loaded into an open aluminum pan. The DSC was operated under inert conditions by purging in nitrogen $\left(99.9 \% \mathrm{~N}_{2}\right)$, and the analysis was carried out with a temperature program $10^{\circ} \mathrm{C} / \mathrm{min}$ from $0^{\circ} \mathrm{C}$ to $120^{\circ} \mathrm{C}$ and then $30^{\circ} \mathrm{C} / \mathrm{min}$ from $120^{\circ} \mathrm{C}$ to $500^{\circ} \mathrm{C}$ and hold for 10 minutes. The area under the curve is calculated as the energy for pyrolysis as shown in Figure 8.

The reference pan is cancelled, and the remaining area under the curve is equivalent to the energy needed for pyrolysis. The area under the curve was calculated as $2.2 \mathrm{MJ} / \mathrm{kg}$ of algae solids (10\% moisture content). Hence, the energy needed for pyrolysis was calculated as $2.44 \mathrm{MJ} / \mathrm{kg}$ of dry algae biomass (0\% moisture). Earlier studies [18] have reported that the values of heat of pyrolysis for pine wood and hardwood biomass was found to be $2.5 \mathrm{MJ} / \mathrm{kg}$ and $3.6 \mathrm{MJ} / \mathrm{kg}$, respectively.

The total energy input is calculated as $8.78 \mathrm{MJ} / \mathrm{kg}+$ $2.44 \mathrm{MJ} / \mathrm{kg}=11.22 \mathrm{MJ} / \mathrm{kg}$ of dry algae biomass.

3.8. Energy Content of the Products. The pyrolysis of the algae biomass produces three different products such as char with a calorific value of $7 \mathrm{MJ} / \mathrm{kg}[28,29], 32 \mathrm{MJ} / \mathrm{kg}$ bio-oil of (experimentally determined by GC analysis), and gas of 5$13 \mathrm{MJ} / \mathrm{kg}[20,28,29]$. Figure 9 shows the energy content of the different products obtained via pyrolysis of algae biomass (after lipid extraction).

Figure 10 shows energy balance for pyrolysis of algae biomass (with lipids). The yield of pyrolysis products under 


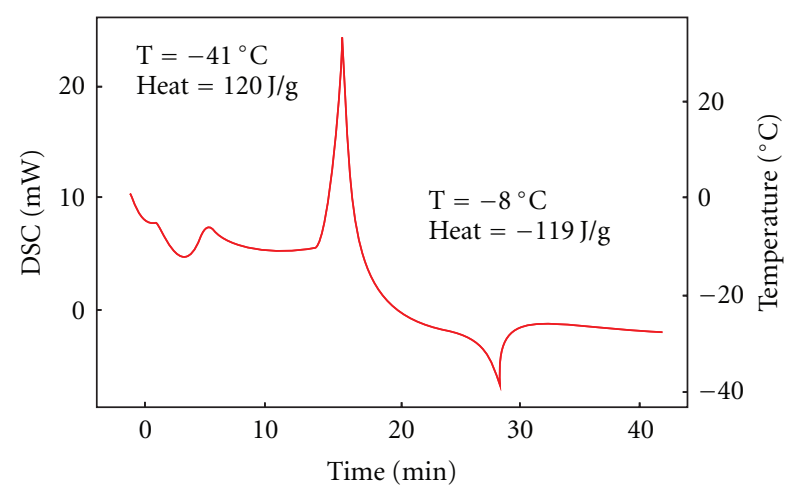

(a)

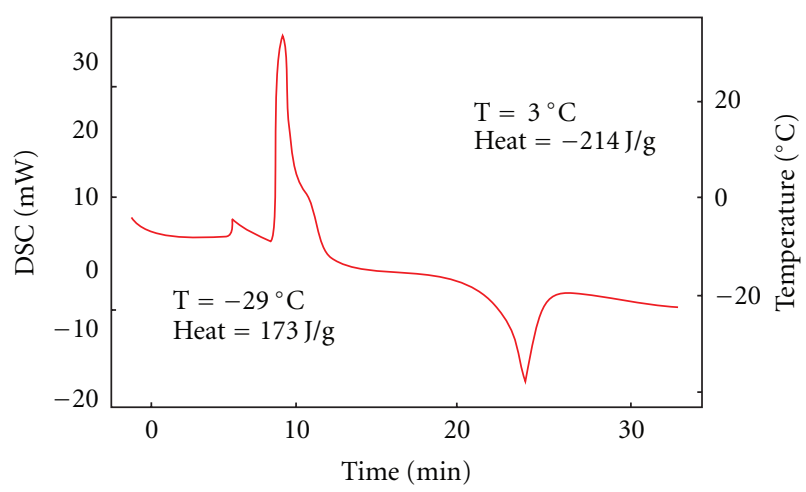

(b)

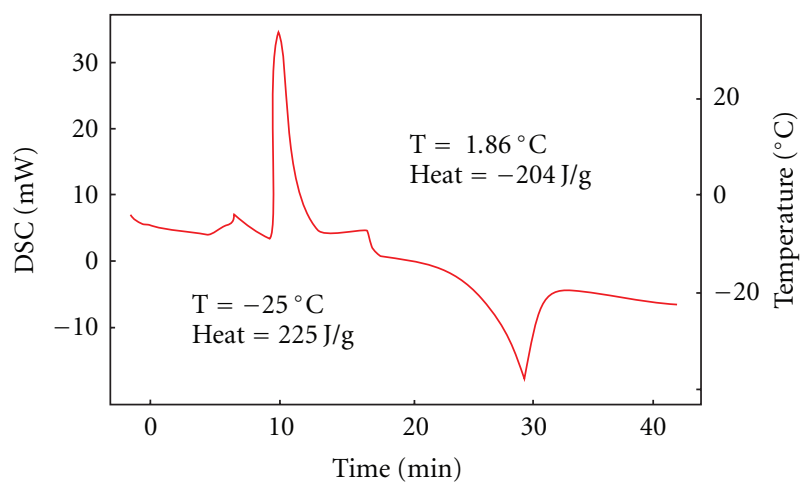

(c)

Figure 6: Thermal analysis of the bio-oil product: $200^{\circ} \mathrm{C}(\mathrm{a}), 300^{\circ} \mathrm{C}$ (b), and $400^{\circ} \mathrm{C}$ (c).

the same conditions for algae biomass (after lipid extraction) as shown in Figure 4(b) is gas: $30 \%$, residue: $50 \%$, and liquid: $20 \%$, and their energy content is $1.5 \mathrm{MJ} / \mathrm{kg}$ for gas (assuming the calorific value of gas is $5 \mathrm{MJ} / \mathrm{kg}$ ), $6.4 \mathrm{MJ} / \mathrm{kg}$ for oil, and $3.5 \mathrm{MJ} / \mathrm{kg}$ for soild:

Total energy output $=11.4 \mathrm{MJ} / \mathrm{kg}$ of dry algae solids.

Total energy input $=11.22 \mathrm{MJ} / \mathrm{kg}$ of dry algae solids.

The yield of oil is high at temperatures ranging from $300^{\circ} \mathrm{C}-350^{\circ} \mathrm{C}$. The yield of pyrolysis at $300^{\circ} \mathrm{C}$, heating rate of $30^{\circ} \mathrm{C} / \mathrm{min}$ and residence time of 0.5 hours for algae biomass with lipids is given as follows: gas: $20 \%$, oil: $30 \%$, and residue:

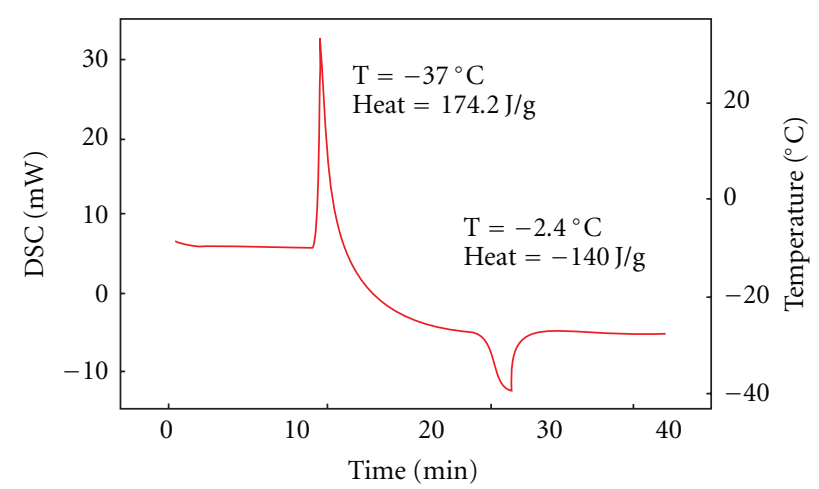

FIGURE 7: Thermal analysis of the bio-oil at $300^{\circ} \mathrm{C}$ (biomass without lipids).

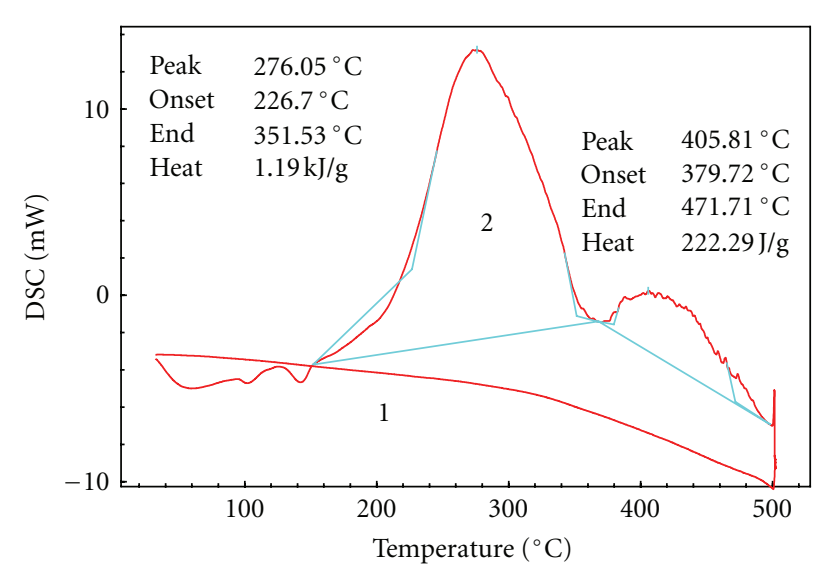

Line 1:- reference pan

Line 2:- sample pan

FIGURE 8: Energy needed for pyrolysis by DSC analysis.

$50 \%$ and their energy content is $1 \mathrm{MJ} / \mathrm{kg}$ for gas, $3.5 \mathrm{MJ} / \mathrm{kg}$ for solid, and $9.6 \mathrm{MJ} / \mathrm{kg}$ for oil:

Total energy output $=14.1 \mathrm{MJ} / \mathrm{kg}$ of dry algae solids.

Total energy input $=11.22 \mathrm{MJ} / \mathrm{kg}$ of dry algae solids. Hence, from the above data it can be stated that large amount of energy is invested in drying the biomass because of high moisture content $(80 \%)$ and high latent heat of vaporization of water. The energy output is almost equal to the energy input.

\section{Conclusions}

The Nannochloropsis sp. CCMP525 produces FFA as high as $27 \mathrm{wt} \%$, and the lipids are highly polyunsaturated, which makes it unsuitable for biodiesel production. Although the unsaturated fatty acids with four or more double bonds can be easily reduced by partial catalytic hydrogenation, this will add to the cost of biodiesel production. However, the algal cells can accumulate less FFA and polyunsaturated fatty acids provided they are cultivated under stress or controlled conditions $[5,6]$. 


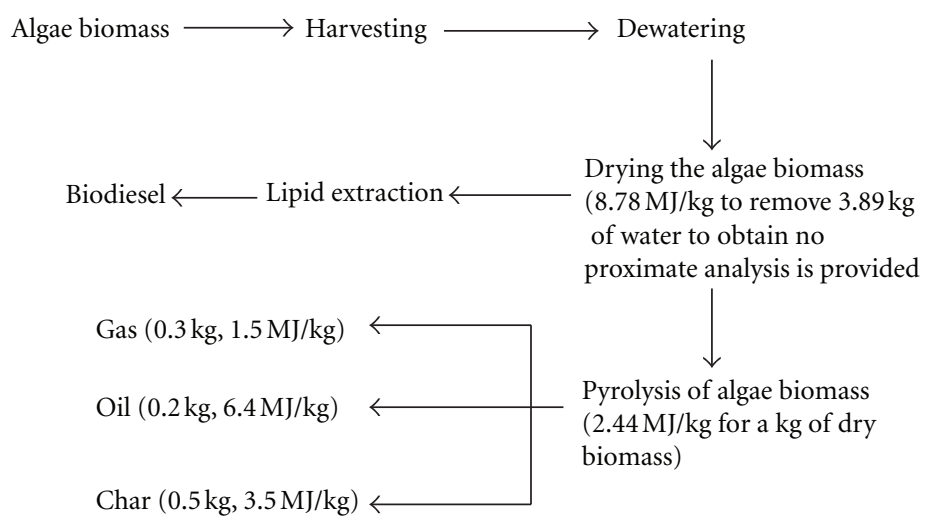

FIGURE 9: Schematic representation of energy balance for pyrolysis of algae biomass (after lipid extraction) carried out at $300^{\circ} \mathrm{C}$.

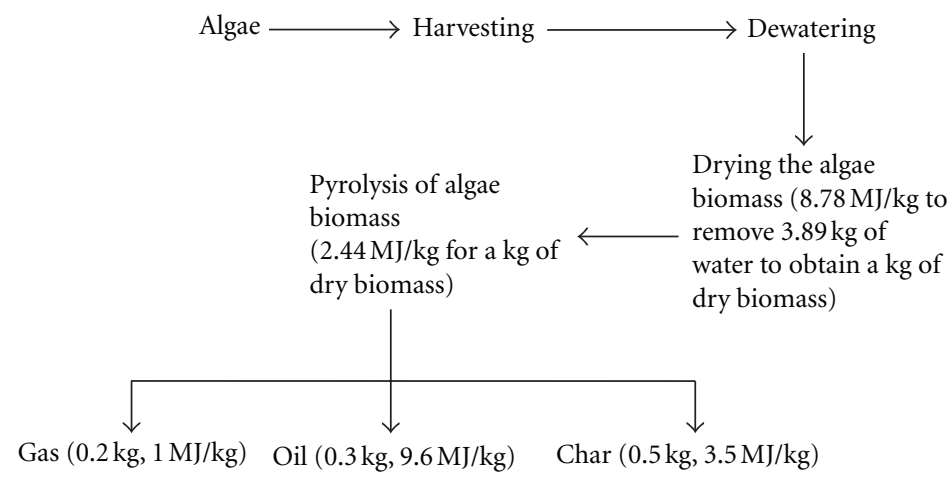

FIGURE 10: Schematic representation of energy balance for pyrolysis of algae biomass (with lipids).

The pyrolysis of algae biomass (after lipid extraction) is more sustainable than pyrolysis of algae biomass (with lipids) because the energy invested in drying serves two purposes, that is, extraction of lipid for biodiesel production and pyrolysis to produce hydrocarbon gas and oil. Also, energy needed for pyrolysis of algae biomass (after lipid extraction) is much less compared to pyrolysis of algae biomass (with lipids) [13]. However, energy required for extraction of lipids followed by energy for biodiesel production needs to be investigated.

The bio-oil produced from pyrolysis of algae biomass (after lipid extraction) is composed of mostly acetone (50\%) and 2-butone (30\% MEK). Hence, it could be used as a fuel for boilers or for the production of industrial chemicals. Maximum yield of bio-oil was produced at temperature $300^{\circ} \mathrm{C}$ with a calorific value of $32 \mathrm{MJ} / \mathrm{kg}$. The residue could be used for carbon sequester and to retain moisture in the soil but further analysis for nitrogen, phosphorus and potassium needs to be investigated. The algae biomass requires much lower pyrolysis temperatures $\left(300^{\circ} \mathrm{C}-350^{\circ} \mathrm{C}\right)$ to produce biooil compared to wood biomass.

It can be concluded that in order to produce biodiesel economically and comply with ASTM standards, cultivating microalgae under stress or controlled conditions could be more sustainable.
Thermal degradation of algae biomass (60\%-80\% moisture content) in supercritical water reactors or thermal liquefaction (wet pyrolysis) could be more sustainable as drying can be avoided.

However, there are problems to be solved especially mass cultivation and harvesting of the algae cells economically. Algae may play a vital role in production of hydrocarbons and chemicals in the near future.

\section{Appendix}

Estimation of Acid Value of the Lipids. The estimation of acid value of the lipids is as follows:

Acid value $(\mathrm{mg} / \mathrm{KOH}) / \mathrm{g}$ of sample

$$
=\frac{\left(V_{1}-V_{2}\right) \times N \times 56.1}{\text { mass of sample, } \mathrm{g}}
$$

$V_{1}$ is the volume of $\mathrm{KOH}$ used for titration of the lipids $(\mathrm{mL})$, $V_{2}$ is the volume of $\mathrm{KOH}$ used for titration of the blank $(\mathrm{mL})$, $N$ is the normality of $\mathrm{KOH}$, Mass of algae lipids $=0.6 \mathrm{~g}, V_{1}=$ $1 \mathrm{~mL}, V_{2}=0.2 \mathrm{~mL}, N=0.1$. 
Substituting the values in (A.1).

$$
\begin{gathered}
\text { Acid value }(\mathrm{mg} \mathrm{KOH}) / \mathrm{g} \text { of sample } \\
=7.46 \mathrm{mg} \frac{\mathrm{KOH}}{\mathrm{g}} \text { of sample. }
\end{gathered}
$$

Five titrations were carried out; the acid values are 8.1060, $7.19,7.287$, and $8.161 \mathrm{mg} \mathrm{KOH} / \mathrm{g}$ of sample. The average acid value is $7.641 \mathrm{mg} \mathrm{KOH} / \mathrm{g}$ of the sample.

Estimation of FFA Content. The estimation of FFA Content is as follows:

$$
\begin{aligned}
& \text { Acid value }(\mathrm{mg} / \mathrm{KOH}) / \mathrm{g} \text { of sample } \\
& =7.46 \mathrm{mg} \mathrm{KOH} / \mathrm{g} \text { of sample, }
\end{aligned}
$$

Molecular weight of $\mathrm{KOH}=56.11$,

$$
\text { Number of moles of } \mathrm{KOH}=\frac{0.0076}{56.11}=0.00013 \text {, }
$$

Average molecular weight of FFA

$$
=275=275 \times 0.00013=0.0372 \text { moles, }
$$

$$
\text { Mass of sample (lipids) }=0.1350 \mathrm{~g} \text {, }
$$

$$
\% \mathrm{FFA}=\frac{\text { FFA mass }}{\text { Total lipids }(\mathrm{g})} \times 100 .
$$

Substituting (A.6) and (A.7) in (A.8):

$$
\% \mathrm{FFA}=27.5 \% \text { or } 27 \% \text { of } \mathrm{FFA} \text {. }
$$

\section{Acknowledgment}

The authors would like to thank the Energy Centre University of Auckland, for the financial support of publication of this paper.

\section{References}

[1] G. Knothe, J. H. van Gerpen, and J. Krah, Biodiesel Handbook, chapter 1, AOCS Publications, 2nd edition, 2005.

[2] L. P. Koh and J. Ghazoul, "Biofuels, biodiversity, and people: understanding the conflicts and finding opportunities," Biological Conservation, vol. 141, no. 10, pp. 2450-2460, 2008.

[3] G. Evans, Liquid Transport Biofuels-Technology Status Report, International Biofuels Strategy Project, 2007, http://www.globalbioenergy.org/uploads/media/0711_NNFC C_-Liquid_Transport_Biofuels_Technology_Status_Report.pdf.

[4] EIA International energy: outlook. Energy Information Administration, Office of Integrated Analysis and Forecasting US Department of Energy, Washington, DOE/EIA- 0484, 2006, http://www.eia.doe.gov/oiaf/ieo/pdf/0484(2010).pdf.
[5] Y. Chisti, "Biodiesel from microalgae beats bioethanol," Trends in Biotechnology, vol. 26, no. 3, pp. 126-131, 2008.

[6] G. A. Thompson Jr., "Lipids and membrane function in green algae," Biochimica et Biophysica Acta, vol. 1302, no. 1, pp. 17$45,1996$.

[7] S. Yokoyama, A. Suzuki, and M. Murakami, "Liquid fuel production from sewage sludge by catalytic conversion using sodium carbonate," Fuel, vol. 66, no. 8, pp. 1150-1155, 1987.

[8] L. Gouveia and A. C. Oliveira, "Microalgae as a raw material for biofuels production," Journal of Industrial Microbiology and Biotechnology, vol. 36, no. 2, pp. 269-274, 2009.

[9] C. Hoek, D. G. Mann, and H. M. Jahns, Algae: An Introduction to Phycology, chapter 1 \& 2, Cambridge University Press, New York, NY, USA, 2nd edition, 1995.

[10] S. Behzadi and M. M. Farid, "Review: examining the use of different feedstock for the production of biodiesel," AsiaPacific Journal of Chemical Engineering, vol. 2, no. 5, pp. 480486, 2007.

[11] S. Fred and T. S. Thomas, "Saccharification of douglasfir wood by a combination of prehydrolysis and pyrolysis," Journal of Applied Polymer Science, vol. 27, no. 12, pp. 45774585, 1982.

[12] http://www.niwa.co.nz/our-science/energy/research-projects all/biofuel-from-wastewater-algae.

[13] W. Peng, Q. Wu, and P. Tu, "Pyrolytic characteristics of heterotrophic Chlorella protothecoides for renewable bio-fuel production," Journal of Applied Phycology, vol. 13, no. 1, pp. $5-12,2001$.

[14] N. Zier, R. Schiene, and K. Fischer, "Structural characterization of an Organosolv lignin by analytical pyrolysis and wet chemical degradation methods," Journal of Analytical and Applied Pyrolysis, vol. 40-41, pp. 525-551, 1997.

[15] M. R. Gray, W. H. Corcoran, and G. R. Gavalas, "Pyrolysis of a wood-derived material. Effects of moisture and ash content," Industrial \& Engineering Chemistry Process Design and Development, vol. 24, no. 3, pp. 646-651, 1985.

[16] W. Peng, Q. Wu, and P. Tu, "Effects of temperature and holding time on production of renewable fuels from pyrolysis of Chlorella protothecoides," Journal of Applied Phycology, vol. 12, no. 2, pp. 147-152, 2000.

[17] X. Miao and Q. Wu, "High yield bio-oil production from fast pyrolysis by metabolic controlling of Chlorella protothecoides," Journal of Biotechnology, vol. 110, no. 1, pp. 85-93, 2004.

[18] T. B. Reed and S. Gaur, "The high heat of fast pyrolysis for large particles, developments in thermochemical biomass conversion," in Developments in Thermochemical Biomass Conversion, A. V. Bridgwater and D. G. B. Boocock, Eds., chapter 1, pp. 97-103, Blackie Academic and Professional, London, UK, 1997.

[19] L. Garcia, M. L. Salvador, R. Bilbao, and J. Arauzo, "Influence of calcination and reduction conditions on the catalyst performance in the pyrolysis process of biomass," Energy and Fuels, vol. 12, no. 1, pp. 139-143, 1998.

[20] K. Raveendran and A. Ganesh, "Heating value of biomass and biomass pyrolysis products," Fuel, vol. 75, no. 15, pp. 17151720, 1996.

[21] Q. Wu, J. Dai, Y. Shiraiwa, G. Sheng, and J. Fu, "A renewable energy source-hydrocarbon gases resulting from pyrolysis of the marine nanoplanktonic alga Emiliania huxleyi," Journal of Applied Phycology, vol. 11, no. 2, pp. 137-142, 1999.

[22] H. Imahara, E. Minami, and S. Saka, "Thermodynamic study on cloud point of biodiesel with its fatty acid composition," Fuel, vol. 85, no. 12-13, pp. 1666-1670, 2006. 
[23] T. Kawai, "Freezing point depression of polymer solutions and gels," Journal of Polymer Science, vol. 32, no. 2, pp. 423-444, 1958.

[24] S. Zabarnick and N. Widmor, "Studies of jet fuel freezing by differential scanning calorimetry," Energy and Fuels, vol. 15, no. 6, pp. 1447-1453, 2001.

[25] P. C. Fourie and D. S. Basson, "Application of a rapid transesterification method of identification of individual fatty acids by gas chromatography on three different nut oils," JAOCS, vol. 67, no. 1, pp. 18-20, 1990.

[26] A. Demirbas, "Biodiesel production via rapid transesterification," Energy Sources, Part A, vol. 30, no. 19, pp. 1830-1834, 2008.

[27] Y. Keiko, T. Mutsumi, and Y. Toshiomi, "Nitrogen depletion for intracellular triglyceride accumulation to enhance liquefaction yield of marine microalgal cells into a fuel oil," Journal of Marine Biotechnology, vol. 6, no. 1, pp. 44-48, 1998.

[28] A. Domínguez, J. A. Menéndez, M. Inguanzo, and J. J. Pís, "Production of bio-fuels by high temperature pyrolysis of sewage sludge using conventional and microwave heating," Bioresource Technology, vol. 97, no. 10, pp. 1185-1193, 2006.

[29] S. Grierson, V. Strezov, G. Ellem, R. Mcgregor, and J. Herbertson, "Thermal characterisation of microalgae under slow pyrolysis conditions," Journal of Analytical and Applied Pyrolysis, vol. 85, no. 1-2, pp. 118-123, 2009. 

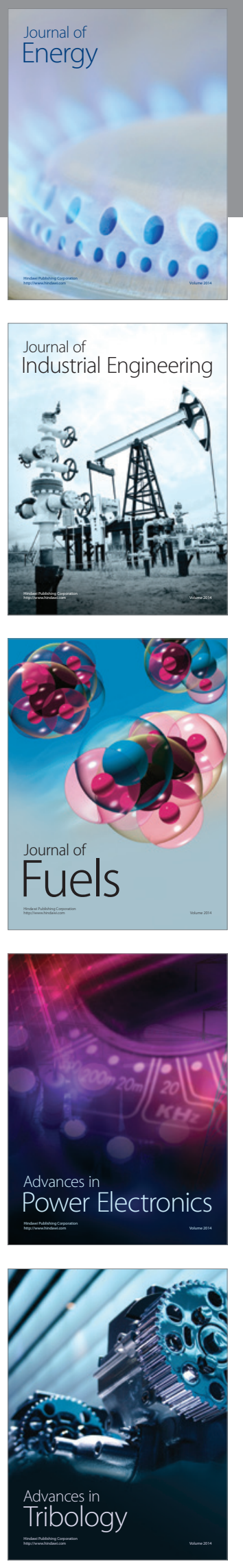
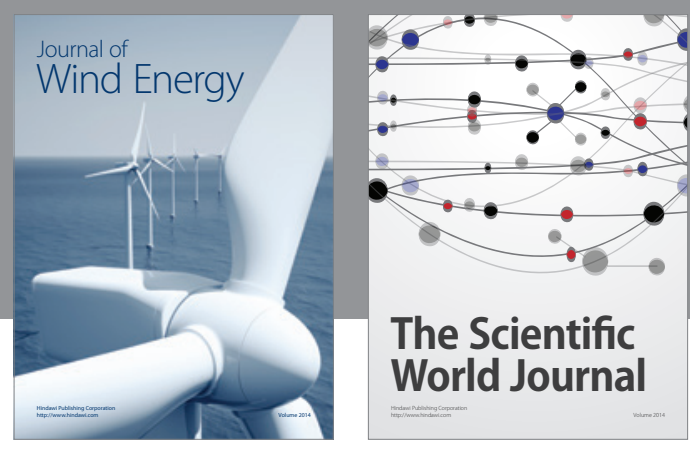

The Scientific World Journal

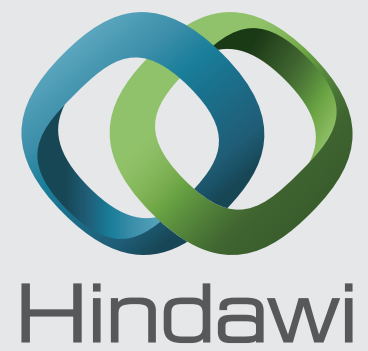

Submit your manuscripts at http://www.hindawi.com
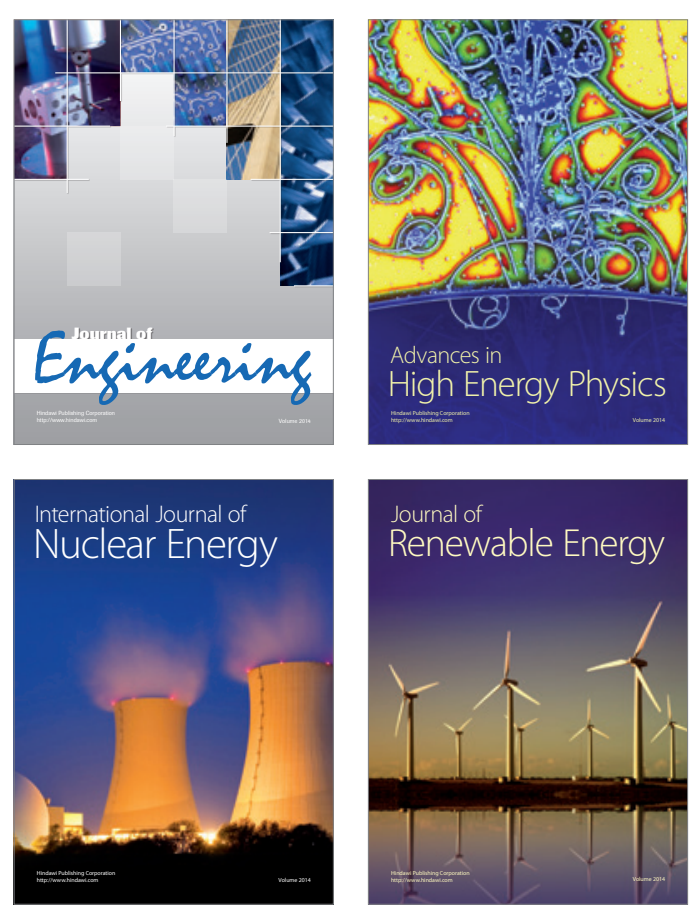

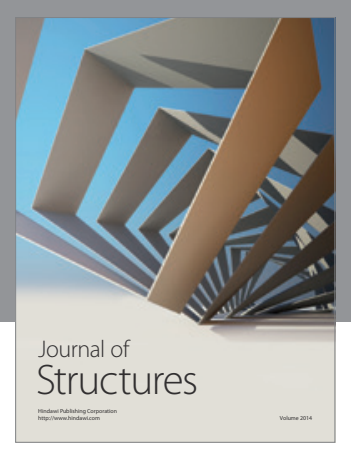

Rotating
Mechinery
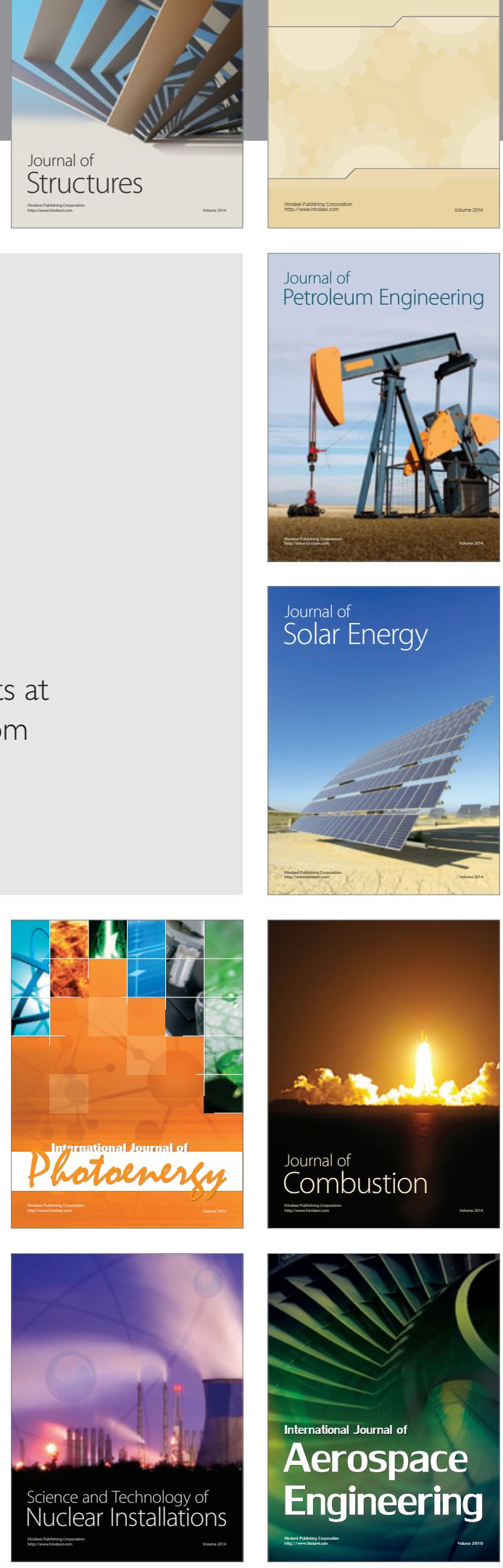